\title{
Controlling the Utilization of Foreign Workers in East Java
}

\author{
Rifki Eka Putra* \\ Faculty of Law \\ Trunojoyo University Of Madura \\ Bangkalan, Indonesia
}

\author{
Misbahul Munir \\ Faculty of Law \\ Trunojoyo University Of Madura \\ Bangkalan, Indonesia
}

\author{
Devi Rahayu \\ Faculty of Law \\ Trunojoyo University Of Madura \\ Bangkalan, Indonesia \\ rahayudevi78@yahoo.com
}

\begin{abstract}
The context of Economic globalization makes every country needs foreign workers, as well as employers in Indonesia. In the provisions of labor regulations and also the FW use supervision. There are 3469 foreign workers that working in East Java, spread in Surabaya, Gresik, Sidoarjo, Mojokerto and Pasuruan. The FW supervision process is carried out by the East Java Labor and Transmigration Office and Immigration. There are various problems in the foreign workers use, such as working not according to the contract, not having work visa and expired work period but still working. This research was conducted to determine the regulation and implementation of foreign workers supervision in East Java. The research method used in this research is empirical juridical with fact approach. Data analysis was performed descriptively. The foreign workers use is based on Law No. 13 of 2003, Presidential Decree No. 20 of 2018 and East Java Regional Regulation No. 8 of 2016. The foreign workers use in East Java has been in accordance with regulatory requirements. This has also been done by PT TS. However, the permit used by the Foreign Worker is the permit that was firstly administered at the time of working start without taking care of the Permit to Use Foreign Workers (PUFW). Supervision has been carried out by East Java Labor and Transmigration Office, only this is done once a year due to the lack of supervisors. The supervision process is carried out in coordination with the Immigration Service as supervisor and grantor of residence permit for foreign workers so that there are no more violations of the contract extension of the Foreign Workers.
\end{abstract}

\section{Keywords: Foreign workers, Controlling}

\section{INTRODUCTION}

Globalization is process of global social order that is unlimited or not recognizes boundaries, globalization is also necessity that inevitably enters our territory, a world economic order that leads to free market. One of the features of globalization is that the economies in international markets are integrated and connected each other in unlimited global environment.[1] Included in the foreign workers use from various countries is also a necessity.

Based on these conditions, in hiring foreign workers, must be done through mechanisms and procedures that are very strict, such as employing foreign workers has been regulated in law No. 13 of 2003 concerning Labor and governmental regulation number 97 of 2012 concerning traffic control levies. and levies for extending permit to employ foreign workers.[2] Foreign workers can be employed in Indonesia only in work relationship for a certain position and time, the company or employer must have written permit from the minister or an official appointed to make permit to use foreign workers (PUFW), foreign workers themselves must have PUFW.[3]

At the end of 2016 as many as 3469 foreign workers worked in East Java, about $40 \%$ came from China they were spread in the ring one industrial area namely Surabaya, Gresik, Sidoarjo, Mojokerto and Pasuruan, most of them entered East Java on tourist visa, but the rest in East Java they work relying on permit from the employing company [4], according to the regulation of the Minister of Labor Number 3 of 1990, which has the authority to supervise the implementation of regulations concerning the granting of permit to employ migrant workers is the labor inspector of the Ministry of Labor.[5]

Based on the Minister of Labor Regulation Number 16 Year 2015 concerning Procedures for the Foreign Workers Use (Permenaker 16/2015), for Employers wishing to use foreign workers must first submit a Plan of Foreign Workers Use (PFWU). The PFWU becomes the basis for the issuance of Permits to Use Foreign Workers (PUFW). The employer must first submit the PFWU to the Minister of Labor or the appointed Officer, in accordance with Article 6 of the Minister of Labor Regulation No 16/2015. According to Article 7 of the Minister of Labor Regulation No 16/2015, to get the ratification of the PFWU, the employer must submit an application in writing or online to the Director General of Labor Placement through the Director of Labor Control (Director of PPTK).

In general, PFWU can be given to employer for maximum period of 5 (five) years and can be extended for the same period by taking into account the conditions of the domestic labor market. Under certain conditions the PFWU can be given in short time and cannot be extended depending on the nature and type of work required by the Employer. PFWU as referred to above can be used as basis for making PUFW.

Problems arising in connection with the foreign workers use in Indonesia are violations of residence permits and work permits. In the passports of these foreign workers, it is written that the permit granted by the Indonesian government by the immigration authority is to work as foreign worker in Indonesia with certain position and time but is misused by being used for a longer period.

Increasing the number of foreign workers who work in East Java, the East Java regional government needs to address in local regulation draft (raperda) regarding levies 
for extending permits to employ foreign workers in value to be an appropriate necessity to increase foreign labor traffic surveillance in East Java.[6] Because many foreign workers who continue to work but exceed the limits of work permits that have been set. Based on the presentation, it will be examined how to monitor the use of foreign workers in East Java.

\section{RESEARCH METHOD}

This research type used in this paper is empirical legal research, which is used to determine the application and implementation of law in society.[7] Empirical legal research is empirical truth that bases facts or symptoms that are evident in society.[8] This research is based on normative jurisprudence (laws and regulations) but is not examining the norm system in the rule of law, but observing how the reactions and interactions occur when the norm system works in society. This research was conducted to determine the placement of foreign workers and supervision of the implementation of Foreign Workers in East Java Province. The method of approach used in this paper based on the background and formulation of the problem described above is to use a fact approach, which is conducting research raising an empirical fact that occurs in society [9] Regarding the nature of this research including analytic descriptive research that is in analyzing the desire to provide an overview or exposure of the subjects and objects studied by the authors as a result of the research. This research was conducted by taking data in the Department of Labor, Transmigration of East Java Province and PT TS.

Primary data in this study were obtained based on direct information from the Department of Labor, Transmigration, and Population of East Java Province, especially data on PUFW arrangements and PUFW extension procedures for foreign workers in the area of East Java Province. Secondary data in this study are previous studies relating to the placement and use of foreign workers in the territory of the Republic of Indonesia. Research data collection was carried out by conducting interviews with relevant parties and document studies. Data analysis method used in this research is descriptive analysis, which is a research procedure that provides exposure to research objects as the results of research conducted". [9]

\section{RESULT AND DISCUSSION}

\section{Procedure for Placement of Foreign Workers in Indonesia}

Foreign Workers, here in after referred to as (FW), has the understanding of every foreign citizen holding visa with the intention to work in Indonesian territory. [10] The purpose of using FW is to meet the needs of skilled and professional workers in certain fields that have not been occupied by local workers and as stage in accelerating process of national and regional development by gaining scientific, technological expertise and increasing foreign investment in the presence of FW as a supporter of development in Indonesia despite the fact that companies in Indonesia whether foreign or national private companies are obliged to use Indonesian experts. [11]

Meanwhile, according to Budiono himself, the understanding of FW is every person who is not an
Indonesian citizen who is able to do work, both inside and outside the employment relationship, in order to produce services or goods to meet the needs of the community. [12] But FW is forbidden to occupy a position in charge of personnel or certain positions and certain positions as referred to in paragraph 1 shall be regulated by Ministerial decree. [13]

Every FW who will work in Indonesia must go through procedures in accordance with the regulation of the Minister of Labor Number 16 Year 2015 regarding procedures for the use of foreign workers, for employers who want to use FW services must submit a Plan for the Use of Foreign Workers or the so-called PFWU in advance which is ratified by the Minister or appointed Officer. The planned use of foreign workers as referred to must at least contain the following information, namely: reasons for the use of foreign workers, the position or position of foreign workers in the organizational structure of the company concerned, the period of time for the use of foreign workers, the appointment of Indonesian citizens as companion of foreign workers employed. Foreign workers who are and work in Indonesia are required to submit to and be protected by labor laws. The labor law concerning the protection of FW regulates, among others: permit, duration, planned use of foreign workers, competency standards, appointment obligations of FW companion workers, prohibition to occupy certain positions, compensation obligations and the obligation to repatriate the foreign workers.

Foreign workers who will work in Indonesia must go through the procedure for the placement of foreign nationals in Indonesia starting with the submission of plan of foreign workers use (PFWU) which includes position, number and time period and the plan to replace them by Indonesian workers by the applicant as prospective user TKWNAP as requirement for obtaining permit to employ TKWNAP (PUFW), after TKWNAP users get approval of the PFWU requested from the Minister of Labor and Transmigration, which in this case appoints the Director General for labor placement, then the PFWU can be used for permit to employ foreign workers (PUFW), i.e. written permit given by the Minister of Labor or officials appointed to the applicant to employ TKWNAP in Indonesia by receiving wages or not for a certain time and at a certain position. [14]

\section{Regulation of FW Use and Its Implementation in} East Java

Regulation of Foreign Workers use is contained in articles 42 to article 49 , these regulation begin with the obligations of employers who use FW to obtain written permit, possess Plans of Foreign Workers Use which contain the type of position, the time period for Foreign Workers use, appointment of citizens Indonesia as companion of foreign workers, to repatriate foreign workers to their country of origin after the end of the employment relationship, as well as taking into account domestic market conditions. After some basic principles, the following procedures or mechanisms for using foreign workers are held:

In arranging Foreign Workers work permits, there are at least two parties involved, namely the employer and the prospective Foreign Workers themselves. From the labor side, the employer is trigger for the issuance of prospective 
foreign worker's work permit. Through Article 42 paragraph (1) of the Labor Act, it is required for every employer who will employ Foreign Worker to have written permit from the designated minister of agency. In addition, the employer is also given the obligation to have Plan of Foreign Worker Use (PFWU) which is approved by the minister or appointed official as stated in Article 43 paragraph (1) of the Labor Law.

After that the Foreign Workers receive notification for approval for the use of Foreign Workers that are issued by the Director General of Labor Placement and Expansion of Employment opportunities as the basis for the issuance of ITAS. In the notification containing the period of notification in accordance with the employment agreement, the Foreign Worker employer after receiving notification of the use of FW must pay DKP-FW no later than 1 (one) working day, the notification is used by the Director General of Immigration for the VITAS issuance process, the application for Notification via foreign workers Online.[15]

The plan to use Foreign Worker must at least have: the reasons for the Foreign Worker use, the company concerned, the period of Foreign Worker use, the appointment of Foreign Worker of Indonesian citizens as companion of the Foreign Workers employed. If look at the foreign workers usage plan, then the reason of PT. TS uses Foreign Workers because the largest shareholders of Chinese state companies and heavy equipment industries really need continuous supply of skilled workers because the technology is constantly changing, so PT TS uses Foreign Workers to be employed in these companies due to supervision of performance and the results of production from the company, which is producing heavy equipment for construction materials, there must be a skilled workforce that can operate properly, because PT TS distributes heavy equipment such as excavators, cranes and trucks for development needs, at PT TS there are two Foreign workers originating from Japan, each of the Foreign Workers employed as Expert Workers in the manufacture of heavy equipment placed as supervisor and the other employed as company staff, the Foreign Workers work to make at the design of heavy equipment and look for international markets to market heavy equipment to the global market, the foreign Workers are needed by PT TS because local workers unable to master the role held by the Foreign Workers.

The use of Foreign Workers is maximum of five years and can be extended by considering domestic market conditions, at PT TS the use of Foreign Workers is contracted around three years of work because in the heavy equipment industry for long-term projects, which is one of the factors of PT TS employs foreign workers to make domestic heavy equipment competitive in the global market, because it will be marketed domestically and abroad.[16] The use of Foreign Workers has many positive impacts on PT TS because the use of Foreign Workers which naturally provides benefits to the local Workers, with companion Workforce system then the companion can learn a lot of knowledge from Foreign Workers.

To employ Foreign Workers must make a Plan of Foreign Workers Use (PFWU), after the plan is approved then issued a Permit to Use Foreign Workers (PUFW), Permits to Use Foreign Workers is made at the Ministry of Labor and for extension is carried out in accordance with the location of the Foreign Worker placement is subsequently given the Limited Stay Permit (ITAS), Report to the Police and Domicile Certificate (DC) if the Foreign Worker resides in East Java, if the company or Foreign Worker does not make official documents as stipulated, the company should be subject to sanctions in accordance with the prevailing laws and regulations, from the company that I visited, namely PT Tatsumi Seruni, they have carried out procedures in accordance with what is determined by the government, but here there is less supervision from the government to control the period of the workforce permit at the company due to lack of checking for Foreign Workers that work in East Java, such as for example is it still active as Foreign Workers at the company or not working for the company, because the permit used by the Foreign Worker is the permit that was first administered at time when started working Foreign Workers in East Java and ignored permits to extend Foreign Workers but continued working for the Company.

Presidential Regulation Number 20 Year 2018 does not legitimize the unskilled Foreign Workers, because in article 2 paragraph 1, in accordance with the Foreign Workers that work in Indonesia only for certain positions only and is approved for personnel position, to accelerate and simplify procedure for foreign workers in Indonesia in this presidential regulation the permit to use foreign worker not required as Presidential Regulation Number 72 of 2014 because it does require documents in accordance with the same, in Presidential Regulation Number 20 of 2018 employers who will request Foreign Workers to request a Plan of Foreign Worker Use (PFWU) without having to ask for Permit to Use Foreign Workers.

With the issuance of Presidential Regulation Number 20 of 2018 which eliminates Permits to Use Foreign Workers as one of the conditions for employing Foreign Workers in Indonesia which has significant impact on companies and Indonesian workers, the absence of Permits to Use Foreign Workers (PUFW) means to abolish the obligations of the giver work as written in article 42 of Law No. 13 of 2003 which states that every employer who employs a Foreign Worker has written permission from the Minister or a designated official. This makes it easier for Foreign Workers to enter the Indonesian territory and will make it difficult to control the traffic of Foreign Workers so that there will be more Foreign Workers working in Indonesia and less employment opportunities. Local workers to work in Indonesia, such as PT TS who employs Foreign Workers from Japan who do not take care of permits extend the duration of Foreign Workers if their work permits in Indonesia have expired, but the Foreign Workers have extended work contracts with companies without passing the supervision of government agencies, the government should give severe penalties to companies and Foreign Workers who have violated the provisions of the regulations implemented by Presidential Decree No. 20 of 2018.

As is known, employing Foreign Workers in East Java has been regulated in the East Java Province Regulation No. 8 of 2016 concerning Labor Regulation contained in article 7 ranging from work training, job placement to supervision and sanctions against foreign workers. violating the provision, is given by the Governor of Control of Foreign Workers Use which subsequently in article 31 is approved as a Plan of Foreign Workers Use and the extension of a 
Permit to Use Foreign Workers (PUFW) in the publication of one area is distributed by the Agency Head of Regency or City, where the extension of the Permit is requested no later than 30 working days before the PUFW validity period expires if the expiry of the expatriate employment period expires and Companies that employ Foreign Workers are required to report if there are Foreign Workers whose employment period will expire to the Labor Agency is in accordance with the area of authority because Foreign Workers are required to take care of the Permit to Use Foreign Workers (PUFW). Therefore, in order to give approval to the levy for extending the work permit for Foreign Workers, it is the authority of the regency or city government to request approval for the regional regulation for the levy for extending Permits to use foreign workers who will increase regional budget funds from the regional retribution sector and will filter foreign workers who are still working in East Java or have returned to their countries, because they must comply with Article 8 of the East Java Governor's Regulation No. 19 of 2017, namely the employer of Foreign Workers must submit PUFW revocation if they do not employ Foreign Workers before the work permit expires.

To supervise foreign workers in East Java the government must be strict in supervising companies that employ foreign workers, PT Tatsumi Seruni itself has been employing foreign workers for 3 years to extend an annual contract with the company without reporting to the local government office if the permit is extended. because it is very contradictory in Article 10 of East Java Governor Regulation No. 19 of 2017, Foreign Workers are obliged to report the use of Foreign Workers in the company every month to the Office, in order to facilitate controlling the traffic of Foreign Workers working in East Java, and if there are foreign Workers who do not comply with the PUFW extension regulations, it must be subject to Article 34 of East Java Province Regional Regulation No. 8 of 2016 concerning Labor Arrangement The Governor has the authority to revoke Permit to Use Foreign Workers or PUFW extensions for companies that employs Foreign Workers across regencies or cities that are not in accordance with the Permit to Use Foreign Workers or PUFW.

Of the various regulations governing the use of $\mathrm{FW}$, namely: Law No. 13 of 2003, Presidential Decree No. 20 of 2018, Permenaker No. 16 of 2015 and East Java Regional Regulation No. 8 of 2016, it can be said that so far the existence of the use of FW in East Java has been in accordance with existing labor law provisions and procedures for using FW that have been determined have been fulfilled and implemented by companies in East Java. One of them was done by PT TS in recruiting FW in the company.

\section{Controlling of Foreign Workers Use in East Java}

The form of authority is expressed in the form of educational preventive supervision, non-judicial repressive, repressive. Supervision authority guided by Law No. 06 of 2011, concerning immigration. As an embodiment of the enforcement of the sovereignty of the territory of Indonesia within the framework of regulating daily life and the State which borders a just and prosperous society based on Pancasila and the laws of the Republic of Indonesia in 1945.
Governmental Regulation No. 31 of 2013, concerning the implementation of Law No. 06 of 2011 concerning immigration which has one of the general provisions of a residence permit for foreign citizenship is a permit granted to foreigners by immigration officials or foreign service officials to be in the Territory of Indonesia. No. 13 of 2013 Presidential Regulation No. 20 of 2018, Permenaker No. 10 of 2018, and Perda No. 08 of 2018, about monitoring foreigners. With this, the formation of a Foreigners Monitoring Team was based on Governmental Regulation Number 31 of 2013 concerning the implementing regulations of Law Number 6 of 2011 concerning immigration, which is regulated in articles 194 through article 201. Further provisions regarding the formation of Foreigners Monitoring Team are regulated by Ministerial regulations. So the birth of the regulation of the Minister of Law and Human Rights of the Republic of Indonesia Number 50 Year 2016 concerning the Foreigner Monitoring Team, the formation of agencies or government institutions known as the Pora Team has duties and functions related to the conditions and activities in the supervision of foreign workers residing in Java East.

Sanctions derived from stipulations for foreign workers (FW), include administrative sanctions consisting of delaying services provided to foreign workers (FW) who commit violations as follows:

a. Not including the foreign workers (FW) in the insurance program at an Indonesian legal entity insurance company that works for less than 6 months.

b. Not including the foreign workers (FW) in the national social security program that works for minimum of 6 months.

c. Does not report annually to the minister regarding the implementation of the use of foreign workers (FW) and the implementation of companion and training of companion workers.

d. Not reporting the end of foreign workers use (FW).

After service delay as form of initial sanctions given continue with the sanction of temporary suspension of the process of licensing foreign workers (FW) given to employers of foreign workers (FW) who commit violations: do not have PFWU authorized by the minister or appointed official, not appointing companion to assist the transfer of technology and foreign workforce (FW), do not carry out education and training for companion, do not facilitate Indonesian language education and training like foreign workers (FW) employed. Furthermore, the sanction of revocation of notification is intended for employers who employ foreign workers (FW) in positions closed to $\mathrm{FW}$. And companies that do not pay DKP-FW for each FW employed. And also other sanctions in accordance with statutory regulations.

There are 6 of the Asian countries that have the most workers in East Java, namely China, Japan, South Korea, Taiwan, the Philippines and India. In this case it will be a challenge for the government, which needs to be more advanced in the supervision of Foreign Workers who will work in East Java by carrying out supervision of Foreign Workers who will work in East Java on the legal basis of 
Law Number 13 of 2003 concerning labor (articles 42-49) and Presidential regulation (Perpres) No. 20 of 2018 on the use of foreign workers have stipulated how to use foreign workers, both those who are prohibited and can be employed

The Immigration Authority has the authority to oversee the crossing of Foreign Workers between countries that will enter Indonesia, the task of immigration is to process the entry of foreign nationals who will work until the exit process of foreign nationals residing in East Java, because many Foreign Workers have work permits has ended but continues to work and many also remain in Indonesia, therefore it is regulated in law No. 6 of 2011 concerning Immigration.

While the authority of immigration as policy towards foreigners prevail in Indonesia through 2 (two) things, namely the prosperity approach, namely foreigners who are permitted to enter, reside and carry out activities in the territory of Indonesia that truly bring benefit for the prosperity and welfare of the Indonesian people, in addition, through security approach that allows immigration licensing is only for those who will not endanger the security of the State and public order. The immigration control system is carried out in 2 (two) ways:

a. Administrative supervision, regulated in article 67 and article 68 of law number 6 of 2011 concerning immigration,

b. Operational supervision, regulated in articles 69 through article 74 of Law Number 6 of 2011 concerning immigration.

Enforcement processes carried out by the Department of Labor and Transmigration in the field of labor inspectors to companies that employ non-procedural Foreign Workers include:

1. Administrative punishment is given as part of the consequences of acts committed by company in this case employing Non-Procedural Foreign Workers, the action is carried out by appointed officials in the form of temporary suspension of the licensing process of Foreign Workers.

2. In the event that labor inspection finds that Foreign Worker violates labor norms, the Director General of Development, Supervision and Occupational Safety recommends to the Director General of Immigration to do immigration action toward foreign workers in accordance with law and regulations.

\section{CONCLUSION}

The conclusions that can be drawn from this research are: The use of foreign workers in East Java in its implementation is in accordance with these provisions. This has also been done by PT TS in the process of recruiting and using Foreign Workers in accordance with labor regulations. However, the permit used by the Foreign Worker is the permit that was first administered at the start of work. In the sense that the foreign worker has expired his contract.
Here Foreign Workers disregard Foreign Middle Work contract permits without going through a Foreign Workers Extending Permit (IMTA). The government has the right to impose sanctions on companies that have been proven to violate administrative sanctions such as service delays, termination of the process of Foreign Workers, revocation of notifications, and other sanctions contained in the legislation, presidential regulation no 20 of 2018 article 34 concerning the use of foreign workers. Therefore the government is expected to provide more optimal controlling of foreign workers who work in companies, especially in the East Java region

\section{REFERENCES}

[1] Budi Winarno, Globalization, Opportunities or Threats to Indonesia. Jakarta: Erlangga, 2008.

[2] Republic of Indonesia State Gazette, Republic of Indonesia State Gazette No 16 of 2015 concerning Minister of Labor Regulation. Indonesia, 2015.

[3] Suhandi, "Labor Arrangement of Foreign Workers in the Implementation of the Asean Economic Community in Indonesia," J. Perspect., vol. Volume 21, no. No. 2 of 2016, May Edition, 2016

[4] Metrotvnews.com, "Metrotvnews.com (www.metrotvnews.com) accessed December 14 2016," Metrotvnews.com, 2016. .

[5] S. M. h. A.R Budiono, Labor Law in Indonesia. Jakarta: PT Raja Grafindo persada, 1995.

[6] Sindo Daily, "Sindo Daily," February 27 edition, Jakarta, 2020.

[7] Zainuddin Ali, Legal Research Methods. Jakarta: Sinar Grafika, 2014.

[8] M. F. N. and Y. Ahmad, "Dualism of Normative and Empirical Legal Research," 2007.

[9] Abdul Kadir Muhammad, Law and Legal Research. BANDUNG: Aditya Bakti, 2004.

[10] Republic of Indonesia, See Article 1 number 1 of Law Number 13 of 2003 concerning procedures for ratifying plans for the use of foreign workers. 2003.

[11] HR Abdussalam, Labor law. Jakarta: Restu agung, 2008.

[12] A. Khakim, Fundamentals of Indonesian Labor Law. BANDUNG: Citra Aditya Bakti, 2014.

[13] Republic of Indonesia, See article 46 of Law No. 13 of 2003 concerning Labor. 2003.

[14] S. Annynomous, "” Placement of Foreign Workers in Indonesia ", posted on November 29, 2016, at 22:30 WIB URL: http://repository.unair.ac.id/id/eprint/47576," 2016. [Online]. Available: http://repository.unair.ac.id/id/eprint/47576.

[15] Author, "Excerpted from the results of an interview with: Sugeng Lestari. Head of work placement. On Thursday, January 31, 2019," 2019.

[16] Author, "Excerpted from the results of an interview with: Ewang, Staff of PT. Tatsumi Seruni, On Friday, December 20, 2019," 2019 